\title{
The Effect of Previous Translations on Retranslation: A Case Study of Russian-Dutch Literary Translation
}

\author{
Piet Van Poucke \\ Ghent University
}

\section{Introduction}

In this paper, the concept of "retranslation" will be used in its meaning of "a new translation produced in the same language where a previous translation of the same text already exists" (Koskinen 317). Literary and other texts have been translated and retranslated throughout history, and as mentioned by Lawrence Venuti, all acts of retranslation share one common purpose - the creation of a kind of "value", whatever that value may represent for the translator, the editor or the commissioner of the retranslation. Since the 1990s, Translation Studies has devoted many studies to the concept of retranslation and a long list of possible motives for retranslation have been defined since then. The vast majority of suggested motives for retranslation seem to have one particular characteristic in common: retranslations aim at presenting a better or enhanced version of the previous translation. Without the purpose of removing the 'deficiencies' of an older translation or enhancing its quality, the act of retranslating would seem to make little sense, so it is self-evident that retranslations are often broadly advertised as "new" and "refreshed" versions of older translations due for "replacement", even if the changes to previous versions are not necessarily for the better. In some specific cases, the marketing strategy even masks the fact that the reader is not really dealing with a retranslation, but with a mere revision of an older translation.

The crucial difference between translating and retranslating a text is that a retranslator has the opportunity to (and perhaps should always) use the previous translation to get acquainted with at least one possible way of translating the source text (ST), and be able to recycle those particular sections of the translation that show no obvious deficiencies and, hence, can be reused in the new version without harming the final result. Since in a number of cases, there is only one obvious translation of a certain word or phrase available, it would be far-fetched to try and replace it. However, what if the proportion of text that could be reused in the new translation were to be so substantial that the new version would hardly differ from the previous one? Does it make sense to retranslate at all in such a case? From which point on are we dealing with a "retranslation proper" instead of a revision or simple refreshing of the older translation? And how do retranslators cope with the presence of particularly successful lexical, syntactic or stylistic choices by the first translator(s)? After all, Antoine Berman pointed out that the continuous process of retranslating would, in the end, lead to the creation of a "great translation" (Fr. grande traduction) that would come so close to perfection that retranslations would become superfluous (Berman 2). However, the practice of literary translation insinuates that this level of perfection is hardly attainable.

The aim of this paper is to study the effect of a first, or previous, translation on the process of retranslating. I would like to find out what are the possible common features shared by retranslations, but absent in other translations, which show no link to each other at all. In order to do that, I will analyze a total of four pairs of literary translations from Russian into Dutch. On the 
one hand I will compare 3 clear retranslations, ordered by one particular publishing house in the Netherlands (van Oorschot), with their predecessors and attempt to identify what they have in common, and what tendencies can be defined with regard to the changes that are introduced in the new target texts (TT). On the other hand, my corpus will include a pair of Dutch translations of one and the same Russian literary work that were made independently from each other and were published virtually on the same day, as the translators were unaware of each other's translation effort. In the latter case, the so-called "previous" (the term is not really applicable in this case) translation could not have had any effect on the "second" translation, making it an interesting case to compare the processes at work with those in the three retranslations proper mentioned earlier.

\section{Retranslation, Adaptation and Revision}

As Outi Paloposki and Kaisa Koskinen correctly stated in their article on the "fine line between retranslating and revising", the exact relationship of a text with the previous translation(s) cannot always be determined, even if the most recent translation is presented as a "retranslation, re-edition or revision" (Paloposki and Koskinen 44). A retranslation is often clearly announced as such on the blurb or in the paratext to the edition out of economic considerations. The reasons why the boundaries between the different categories of revision are so unclear may be attributable to the complex nature of the retranslation process. First of all, although the definitions of the concepts of retranslation and revision seem clear enough (a retranslation is a completely new translation, a revision is a reworked version of an older translation), "retranslators may, or may not, rely on earlier versions to the extent of copying elements from them" and "revisers may, or may not, alter the text extensively" (Koskinen 317), which makes a distinction between the two processes less transparent. Indeed, in practice, the "labels" of "(re)translation, (...) revisions, adaptations and retellings" are "hard to separate and cover different contents" in different circumstances (Van Coillie 39).

Moreover, with the publishing houses realizing the commercial potential of a retranslation superior to that of a re-edition or even revised version, it is natural that they are tempted to recommend their new edition of a canonical (and therefore possibly commercially profitable) literary work as a completely new translation. In many cases, the blurb of the new edition refers explicitly to the novelty of the translation and literary reviews are often overly keen on recommending the refreshed version of a literary translation as being entirely trustworthy. As Koskinen stated, retranslation is clearly seen as a strong marketing device, but the term on its own does not reveal the true nature of the text: "peritextual and paratextual information may not necessarily always be trustworthy, and revealing the true relationship between two translated versions may require close contrastive reading, identifying relevant similarities and differences" (Koskinen 316).

The relationship and interdependence between two different translations of one ST may, indeed, have many faces and also holds an element of ethics. For many centuries, the question of plagiarism was hardly mentioned in the literary industry, as the ethical norms of translation and originality fundamentally differed from contemporary attitudes. As Racz (44) points out, ethical principles of (re)translation surfaced only in the nineteenth century, while the "routine consultation of prior translations" was taken for granted in the preceding period. With regard to these ethics of 
retranslation, Eoyang (as quoted in Racz 44) distinguishes three different approaches: “(1) intertextuality, which is creative license; (2) influence, which is creative opposition; and (3) imposture, which is uncreative theft". To this list, Koskinen, in the Routledge Handbook of Literary Translation (320), adds two more possible approaches - "forceful avoidance of any influence" and "hostility" towards the previous translations.

How a retranslator deals with the work of his/her predecessor is finally a question of personal ethics. Steiner calls the use of previous translations translating "after and against" (412) the existing translation(s), which constructs at the same time an appropriate aggressive metaphor that reflects the distance the retranslator wants to, or has to, observe if $\mathrm{s} /$ he wants to be fully appreciated for his/her originality in the confrontation with (the) earlier translation(s). On the other hand, according to Racz "a retranslator ought to do everything in his/her power to ensure the production of an original and error-free TT. Consulting a prior translation or translations once a T'T draft has been finished thus becomes but one judicious step in the entire enterprise of retranslation, one available uniquely to the retranslator" (Racz 47).

In this process, not only may earlier translations into the same language be included, but also translations into other (mostly central) literary systems, as they have great potential to influence translation policies and processes in other (mostly peripheral) systems (see Alevato do Amaral for a discussion on broadening the notion of retranslation in that direction) ${ }^{1}$. Translations into languages other than the one into which the retranslator is working can, indeed, shed useful light on the meaning or interpretation of certain difficult passages in the ST, especially when the translator is dealing with a canonical literary work or with archaic lexicon and culture-specific expressions.

\section{Methodology}

In this paper, I will try to visualize the effect of a previous translation on a retranslation - or, if looked at from the other side of the mirror, the traces of previous translations in a retranslation by comparing four Dutch translations of classical Russian literary works with their parallel or retranslations. Literary translations are specifically chosen here because they are probably more often retranslated than other types of texts. Moreover, the style and originality of a translated literary text is presumably more important than that of other text types (journalistic, political, historical, scientific and many other types), which allows me to compare the translations not only at the lexical and syntactic levels, but also at the stylistic one.

\footnotetext{
1 The terms "central" and "peripheral" suggest they are within the polysystem theory, which divides languages, cultures and cultural systems into bigger, central entities and smaller, peripheral ones (see Even-Zohar for an introduction to these theoretical concepts).
} 


\subsection{Corpus}

\subsubsection{Three Translations and their Retranslations}

On the one hand, I will compare three recent retranslations with older translations of the same work, published by the same publishing house, and explicitly announced to the reader as a 'refreshed' and reworked translation of the previous one (see Table 1). In these particular cases, the retranslators were fully aware of the existence of another translation and the explicit reference to retranslation virtually forced them to use the previous translation as a starting point for their task. This inclination to consult the previous translation must have been especially high as the literary translations all appeared in the prestigious series of the Russian Library (Du. De Russische bibliotheek) which has been in existence since 1953 and is known for its high-quality translations of canonical Russian literature ${ }^{2}$. The publishing house responsible for the Russian Library, van Oorschot, (rightly) considers the series of translations of classical Russian literature as a "cultural monument" (Hartman) and, at the same time, as an economic product intended to make profit. The economic consideration behind the edition of a series of retranslations, from 2005 on, is obvious on the website of the publishing house (http://www.vanoorschot.nl/productcategory/russische-bibliotheek/), where the new translations are discussed at great length.

Retranslations are often interrelated with the ageing process of translations in general (see Van Poucke 92). However, it is not only the Dutch language, but also the translation norms of the Dutch target culture that have changed over time, and therefore the publishing house decided to order a series of new translations of the Russian classics. As stated by Menno Hartman, one of the publishers of van Oorschot, the retranslators were not asked to "revise" the older versions (which were, in his words, affected by "the ravages of time" anyway), but were expected, instead, to deliver a completely new version of the TT. The publisher stresses that the retranslators were explicitly given carte blanche in order to avoid a sudden change of style within the same translation, which could have been the result in the case of a partial revision (Hartman). In other words, the prestigious nature of the earlier translations is no longer taken into account in the translation policy of the publishing house, and the obvious link with the past is deliberately cut. It is interesting to see how the translators also avoid confrontation with the past in their paratext. The retranslators talk at length about the literary works in the original Russian culture, but do not discuss the previous translation and/or the changes they made into the TT, which is in line with the general modus operandi for literary translators.

In order to avoid the influence of (1) the changing translation strategies over time, and (2) the possible idiosyncratic peculiarities of the specific translation strategy of one particular (but not representative) translator, I will use translations by three different translators and published around the same period. In particular, I will discuss the following pairs of translations and retranslations:

2 Acknowledging the still problematic nature of literary translations from Russian into Dutch in the 1950s on the one hand (because of insufficient knowledge of Russian in Dutch culture and/or the obvious problems connected with the omnipresent indirect translations through French and German), and the opportunities for commercial success on the other, editing house van Oorschot decided in 1953 to start up its own series of high quality literary translations. Skilled and experienced Dutch translators were systematically approached with the request to provide direct translations of the 'classics' of Russian literature into Dutch. 


\begin{tabular}{|c|c|c|}
\hline Source text & Target text 1 (TT1) & Target text 2 (TT2) \\
\hline $\begin{array}{l}\text { Фёдор Аостоевский, Братья } \\
\text { Карамазовы (1879-1880) }\end{array}$ & $\begin{array}{l}\text { F.M. Dostojewski, De } \\
\text { gebroeders Karamazow (1958, } \\
\text { translated by Jan van der Eng) }\end{array}$ & $\begin{array}{l}\text { Fjodor Dostojevski, De broers } \\
\text { Karamazov (2005, translated by } \\
\text { Arthur Langeveld) }\end{array}$ \\
\hline $\begin{array}{l}\text { Аев Толстой, Война и мир } \\
(1868)\end{array}$ & $\begin{array}{l}\text { Leo Tolstoj, Oorlog en vrede } \\
\text { (1966, translated by H.R. de } \\
\text { Vries) }\end{array}$ & $\begin{array}{l}\text { Lev Tolstoj, Oorlog en vrede } \\
\text { (2006, translated by Yolanda } \\
\text { Bloemen \& Marja Wiebes) }\end{array}$ \\
\hline $\begin{array}{l}\text { Антон Чехов, Пассажир } \\
\text { первого класса (1886) }\end{array}$ & $\begin{array}{l}\text { Anton Tsjechow, De passagier } \\
\text { eerste klas (1954, translated by } \\
\text { Charles B. Timmer) }\end{array}$ & $\begin{array}{l}\text { Anton Tsjechov, De passagier } \\
\text { eerste klas (2005, translated by } \\
\text { Tom Eekman) }\end{array}$ \\
\hline
\end{tabular}

Table 1: Overview of source and target texts used within the Russian Library corpus of retranslations

\subsubsection{One Case of 'Parallel Translation'}

On the other hand, I will also analyze two different translations of one and the same Russian literary work, for which I would like to introduce the term "parallel translation" within the boundaries of this paper. The term "parallel" is used here because we are dealing with two different translations of one and the same literary work, but it is virtually impossible to refer to them as a first translation and retranslation as the translations were done independently from each other, with the translators not knowing of each other's efforts:

\begin{tabular}{|l|l|l|}
\hline Source text & Target text 1 (TT1) & Target text 2 (TT2) \\
\hline ВАаАимир ОАоевский, 4338- & Vladimir Odojevski, Het jaar & Vladimir Odojevski, Het jaar \\
$\check{u}$ год: Петербургске письмa & 4338 (2011, translated by & 4338 (2011, translated by Aai \\
(1835) & Willem Weststeijn) & Prins) \\
\hline
\end{tabular}

Table 2: Overview of source and target texts used for the analysis of parallel translations

The two competing translations of Vladimir Odoevsky's utopian The Year 4338 (1835) were published at virtually the same time in 2011, one in a bilingual edition by publishing house Pegasus as part of an academic-oriented series of books Slavic Copybooks (Du. Slavische Cabiers) and translated by Willem Weststeijn, the other by publishing house Hoogland \& Van Klaveren and translated by Aai Prins. Just like in the three cases of retranslation, we are dealing with highly experienced and recognized literary translators, which makes the exercise the more relevant for research purposes. As all 8 translations in the analysis attend the highest quality standards, we avoid the quantitative data (see Table 4) being contaminated by the youthful lapses of an unexperienced literary translator.

\subsection{Method}

When comparing retranslations with their previous versions, on the one hand, and parallel translations on the other, we have to take into account that we may encounter one specific methodological problem. Parallel translations are each other's contemporaries and are, therefore, expected to show a number of similar linguistic features after all, while the (re)translations in this case study significantly diverge from each other with respect to temporal features of linguistic ageing. However, bearing in mind that the ST remains the same in all cases, and that translators, as a principle, try to respect most stylistic features of the original (we are dealing with canonical STs from the rich treasure-chest of classical Russian literature and translations into a prestigious series) we do think the comparison stands up to scrutiny and should reveal at least some tendencies of 
literary retranslation that transcend the generally acknowledged process of refreshing linguistic features of ageing.

The aim of this paper is to analyze the differences between four paired couples of literary translations (three translations with their respective retranslations, and one pair of parallel translations) at lexical, syntactic and stylistic level. First, the lexical choices of the retranslators will be studied quantitatively. In each of the literary works, one section will be selected at random, and within each section, I will compare the lexical choices by the retranslators with the choices made by the first or earlier translators. As the short story by Chekhov has no further subdivisions, I begin the analysis from the start of the story. For $W$ ar and Peace, chapter 20 of the $1^{\text {st }}$ part was selected at random, for The Brothers Karamazov, chapter 3 of book 11 (see Table 1). In Odoevsky's The Year 4338 , the $2^{\text {nd }}$ Letter was appointed by lot (see Table 2).

During the analysis, I will ignore the grammatical form of the chosen word(s) and will only compare the translators' choices at the surface level of primary lexicality. Whenever the two translators use the same word (in any form), I will consider this as a "match"; in all other cases, I will count the translations as a "divergence".

Subsequently, the same selected sections will be scanned qualitatively for different translators' choices at syntactic and stylistic level. The term "syntax" is here understood to mean "the way in which linguistic elements (such as words) are put together to form constituents (such as phrases or clauses)" ("Syntax"). In particular, I will look at the changes in the grammatical structures of the sentences. The stylistic analysis will then focus on the "distinctive manner of expression" ("Style") of the ST in translation, which includes a comparison of the register, the tropes and the reproduction of culture specific elements in translation. In this phase of the analysis, I will look for syntactic or stylistic patterns in the retranslations that occur at least twice in the retranslations and for which the previous translation could have been an inspiring factor in the decision process by the retranslator.

\section{Case Study}

\subsection{Lexical Analysis}

The fact that there is a difference between a "retranslation" and a "revision" has been stressed more than once in academia, but that difference has not yet been quantitatively defined and there is no real theory yet on the borderline between the two approaches to the adaptation of an older translation to the norms of the contemporary target culture. In order to gain a rough understanding of the lexical characteristics of retranslation, I will mutually compare samples of the randomly selected sections (see 2.2) and count the number of lexical items that are exactly repeated in the retranslation.

First, I will focus on the first 200 words $^{3}$ in each translation and will determine the percentage of matches between them. The results for the three retranslated works show an overlap of $54 \%$ of

\footnotetext{
${ }^{3}$ As the number of words in the two translations is unequal in most of the cases, I will stop the analysis only at the first full stop after the $200^{\text {th }}$ word and take the average of the two translations in order to calculate the percentages of matches and divergences.
} 
the words on average, with a slightly lower percentage for the retranslations of Chekhov (52\%) and Tolstoy (50\%) and a significantly higher result for the Dostoevsky retranslation (62\%). Despite the limited character of this sample, a preliminary conclusion can be drawn: around 50-60\% of the words in the older translation are apparently 'recycled' in the retranslations. If we compare that with the amount of overlap between the two parallel translations, then we notice only a slightly higher result of $60 \%$ there. No fewer than 136 words are identical in a sample of respectively 225 and 232 words in the two translations.

In order to illustrate the contingent overlap between two 'parallel' translations first, I will use an example taken from the Odoevsky translations, where the amount of almost verbatim repetitions is particularly high:

\begin{tabular}{|l|l|}
\hline Translation by Weststeijn (2011) & Translation by Prins (2011) \\
\hline Eindelijk ben ik in het centrum van het & Eindelijk ben ik in het centrum van het \\
Russische halfrond en de wereldbeschaving. Ik & Russische halfrond en de wereldbeschaving; ik \\
schrijf je terwijl ik in een prachtig huis zit op & schrijf je, gezeten in een schitterend huis, \\
de luifel waarvan met enorme kristallen & waar op het convexe dak in reusachtige \\
letters geschreven staat: Hotel voor & kristallen letters staat geschreven: 'Hotel voor \\
vliegpassagiers. Dat is hier zo de gewoonte: & Inkomende Luchtpassagiers'. Dat is hier zo \\
op de rijke huizen zijn alle daken van kristal & de gewoonte: de rijke huizen hebben allemaal \\
of bedekt met witte kristallen dakpannen en de & kristallen daken of zijn bedekt met witte \\
naam van de eigenaar is aangebracht met & kristallen dakpannen, en de naam van de \\
gekleurd kristal. 's Nachts, als de huizen & eigenaar is vervaardigd uit gekleurde \\
vanbinnen verlicht zijn, vormen deze & kristallen. 's Nachts, als de huizen vanbinnen \\
schitterende rijen daken een betoverende & verlicht zijn, bieden die glinsterende \\
aanblik. Bovendien is deze gewoonte heel & dakenrijen een sprookjesachtige aanblik; \\
handig: je hoeft niet, zoals bij ons in Beijing, & bovendien is dit gebruik zeer nuttig - dat is \\
waar je 's nachts vanboven af je eigen huis & heel wat anders dan bij ons in Peking, waar \\
niet kunt herkennen, niet naar de grond af & je 's nachts met geen mogelijkheid het huis \\
te dalen. & $\begin{array}{l}\text { van je kennissen herkent en je wel } \\
\text { genoodzaakt bent te landen. }\end{array}$ \\
\hline
\end{tabular}

Table 3: Divergences between two samples of the parallel Dutch translations of Odoevsky's The Year 4338 .

Only the words and expressions in bold are not exactly repeated in both Dutch versions of Odoevsky's novel, which suggests that two translators, independently of each other, come up with roughly the same translation solutions for $60 \%$ of the words. This case study seems to suggest that there is an obvious and natural way of translating a ST, at least in those cases where the Russian version is not stylistically complex, as was the case in the used sample. For the translation of stylistically more defiant genres, and in particular for poetry translation, this percentage would probably be lower, but further research on a corpus of parallel translations (providing it is possible to irrefutably prove the absence of mutual influence between two translations) of for instance poetry is required to confirm or reject this intuitive hypothesis.

On the one hand, the lower percentages for the Chekhov and Tolstoy retranslations could be an indication that retranslators deliberately move away from their predecessor and try to repeat fewer words, but on the other, the Dostoevsky sample shows a contradictory result, where the overlap is even higher than in the parallel translations. Without asking the retranslators specifically about their working methods, it is impossible to determine whether they actually came across the 
same finding as their predecessors in some cases and only then decided to strive for originality and move away from the earlier T'T, or whether their translation process led to the TT in its published form in which case the deviations from the older versions would be natural and not affected by a desire to create an original translation.

Before we dig a bit deeper into the corpus, we remove the bias that might be created by the presence of articles, prepositions and other simple text structures, for which often no acceptable alternative is available. In other words: how many different ways are there to express simple clauses such as, "on the moon" or "in the train"? It could be useful to do the same exercise for the most meaningful lexical items only, i.e. verbs and nouns. Again the translations were compared with one another, but in this phase of the analysis, only the first $100^{4}$ verbs and nouns in each of the analyzed sections were compared with their counterparts. The comparison of the translations gives the following quantitative results:

\begin{tabular}{|c|c|c|c|c|}
\hline \multirow{2}{*}{ Lexical overlap } & \multicolumn{2}{|c|}{ Verbs } & \multicolumn{2}{c|}{ Nouns } \\
\cline { 2 - 5 } & TT1 = TT2 & TT1 $\neq$ TT2 & TT1 = TT2 & TT1 $\neq$ TT2 \\
\hline Dostoevsky & 60 & 40 & 69 & 32 \\
\hline Tolstoy & 46 & 59 & 66 & 35 \\
\hline Chekhov & 52 & 48 & 60 & 42 \\
\hline average & $\mathbf{5 2} \%$ & $\mathbf{4 8} \%$ & $\mathbf{6 4} \%$ & $\mathbf{3 6 \%}$ \\
\hline & & & & 37 \\
\hline Odoevsky & 53 & 48 & 64 & $\mathbf{3 7 \%}$ \\
\hline percentage & $\mathbf{5 2} \%$ & $\mathbf{4 8} \%$ & $\mathbf{6 3} \%$ & $\mathbf{6} \%$ \\
\hline
\end{tabular}

Table 4: Number of matches and divergences between the translations of verbs and nouns in the selected samples of the translations in the corpus.

The first result that catches the eye is the surprisingly high similarity between the average for the retranslations on the one hand, and the parallel translations on the other, both for verbs and nouns. While the percentages for the matches for the verbs are completely identical (52\%), the difference for the nouns is only one percentage point - 64\% versus $63 \%$. Even if this result is based on a limited sample, this finding suggests the nature of retranslation is not fundamentally different from translation after all, as the two parallel translators have an almost identical amount of overlap in their lexical choices in comparison with the retranslators.

When we look more closely at the individual cases, there are, of course, more significant differences (and here again the Dostoevsky text stands out), but on average there seem to be no clear cases of plagiarism nor of complete hostility or rewriting of the ST in Dutch. This might be partly explained by the brief the retranslators received from the publishing house (see 2.1.1), but the high percentage of matches can also be explained by the (expected) high quality of the previous translations. Further research could focus on translations published in popular and cheap editions by less experienced (re)translators in order to establish whether the quality expectations of the publishing houses also play a role in this issue.

\footnotetext{
${ }^{4}$ Here again, the exercise was not interrupted in the middle of a sentence, which explains why the sum of the two results in some cases gives a figure that exceeds 100 .
} 
The results of the analysis also seem to confirm the suggestion that there are only a limited number of ways to translate certain lexical items into another language, and that there is no particular reason for avoiding the most obvious lexical choice for the sake of originality. This specific suggestion is partly confirmed (albeit based on a very limited corpus) by the analysis of the two parallel translations: in cases where translators have no earlier translation to consult for inspiration, they have no first version to retranslate against (see earlier) and apparently choose the most obvious verb or noun to express the meaning of the ST. In approximately $50-60 \%$ of the cases, this seems to lead to the same lexical preference. However, this quantitative similarity gives only a hint of what is really going on at other text levels, as will be illustrated further in this paper.

Moreover, one could also ask the question here whether other types of texts (philosophical treaties, essays, opinion articles, and most obviously poetry) would lead to similar results. Racz's analysis of poetry retranslations at least confirms the hypothesis that style is much more important than content, which leads to a more original style of translating and, hence, a higher degree of diversity in lexical choices (Racz). One could expect that originality is of higher priority for poetry retranslators.

\subsection{Syntactic and Stylistic Analysis}

The analysis, so far, shows a number of similarities between retranslations and parallel translations and gives a rough idea of the level of lexical elements that are retained or changed during the retranslation process. The lexical comparison of these small samples evidently only covers part of the story, and it is necessary to look at other aspects of retranslation as well, in order to better define the nature of retranslation. At first sight, the results of the quantitative analysis seem to suggest that the result of the work of retranslators does not significantly differ from the results of parallel translation. Does this imply that the previous translation plays no meaningful role at all, since the $50-60 \%$ of overlap between the translations could also be the case where only one translation is the obvious choice for the (re)translator? Is there any effect at all from the previous translation? In order to answer this question, one has to delve deeper into the more structural parts of the retranslations, i.e. the syntactic and stylistic features. At this point, the retranslations differ significantly from the parallel translations.

\subsubsection{Divergences at Syntactic and Stylistic Levels}

The parallel translations share significantly more syntactic decisions than the translations and their retranslations. Here the temporal factor comes into play, as parallel translations share the same linguistic surroundings and are virtually made for one and the same audience, while retranslators are dealing with a target language and target culture that is different from the previous TT. Some languages seem to age more quickly than others, but even in the case of English, which seems to evolve relatively slowly (see Mair 5-6), retranslations are needed to refresh the language of the older translation.

The Dutch literary language, which is the object of this paper, evolves relatively quickly (see van der Horst and van der Horst for a detailed analysis), and that is why linguistic ageing was a major consideration for the van Oorschot publishing house (Hartman) behind the decision to have the classical works of Russian literature retranslated into Dutch. As both translations of the 
Odoevsky novel reflect the condition of the Dutch language in 2011, there are no significant syntactic shifts between the two versions. Contemporary parallel translators use similar syntactic structures and avoid outdated language. This is obviously not the case with the retranslations, where linguistic rules have changed over the four or five decades that separate the two versions of the TT.

In fact, the sample of literary translations that is used in this paper shows the same characteristics as other retranslations in the Russian Library series (see Van Poucke 108-110): for instance, the reduction of the use of subordinate clauses, participles and gerunds, or the splitting of long sentences into smaller ones. Specifically, in the present corpus, the avoidance of passive and impersonal constructions in the retranslations is noticeable, as can be seen in following example:

(1) Больному Аали чего-то выпить, зашевелились около него, потом опять расступились по местам (TS 94 - The patient was given sometbing to drink, they moved around him, then again moved to their places $)^{5}$

Men gaf de zieke iets te drinken, om hem heen werd zenuwachtig geschuifeld, waarop iedereen zijn oude plaats weer opzocht (TT1 100 - They gave the patient something to drink, around bim there was nervous shuffling, after which everyone returned to their old place)

De zieke kreeg iets te drinken, er was wat beroering om hem heen, daarna ging iedereen naar zijn plaats terug (T'T2 105 - The patient got something to drink, there was some turmoil around him, then everyone went back to his place)

This extract of the ST contains a series of passive and impersonal constructions, and they are in general retained as such in the Dutch translation of 1966. Although the English translation of the Dutch retranslation might suggest otherwise, there is a significant change in syntax and style between the two Dutch versions. Whereas only one of the three clauses in the 1966 version contained an active subject, all three clauses are active in the retranslation. In the 1966 version both the words men (one) and werd (was) referred to impersonal and/or passive constructions, which certainly was in line with the original, but would sound outdated now, which is why the contemporary retranslators had reason to replace the syntactic structures of the original, even if this decision moves the TT virtually away from the original. In other words, the retranslation process moves the TT away from the previous version in order to remove the traces of ageing (see Van Poucke for similar examples).

Other divergences between the first translation and the retranslation are to be found at the stylistic level and here again, the majority of interventions by the retranslator serve to either update the translation, or restore certain features from the ST that had been lost in the previous TT. A

5 In the examples the following codes will be used to refer to the sources: $\mathrm{C}=$ Chekhov, $\mathrm{D}=$ Dostoevsky, $\mathrm{T}=\mathrm{Tolstoy}$. $\mathrm{S}$ is used for the source text, and T for the target text, with the number " 1 " referring to the first translation, and " 2 " to the retranslation in the corpus. The next number indicates the page in the used text edition. The translations between brackets after the examples do not aspire to literary quality but stay as close to the Russian and Dutch originals as possible in order to show the syntactic fingerprint of the Russian and Dutch phrases. 
first example involves the lowering of the register, which is most often encountered in the sections with direct speech:

(2) Вы чем-то расстроены? (DS 288 - Are you upset with sometbing?)

Is er iets waardoor u geprikkeld bent? (DT1 702 - Is there something by which you are irritated?)

Is er iets met $\mathrm{u}$ aan de hand? (DT2 703 - Is there something wrong with you?)

The more modern version of this dialogue sounds much more natural and colloquial than the first version, which makes the conversations much more plausible and credible for a modern audience. Similar examples of this kind of shifts can be found throughout the corpus, as for instance in the Chekhov translations, where околевать (CS 271; here in the meaning of 'to die') is first rendered by er tussenuit knijpen (CT1 36; to decamp), but translated less shrouded by de pijp uitgaan (CT2 397; to kick the bucket) in 2005.

In general, most of the first translations in the Russian Library series suffered from a kind of verbosity that was superfluous, especially in the case of the short stories by Chekhov, who is famous for his verbal austerity (see Van Poucke 108-110). In the corpus for this paper, verbose sections in translation are reduced in order to move the retranslation closer to the ST:

(3) Вы, человек интелмигентный и пожилой, ни разу не слыхали про меня (CS 271 - You, an intelligent and elderly person, have never heard of me)

$\mathrm{U}$ bent een man van intelligentie en niet zo jong meer en toch heeft $\mathrm{u}$ mijn naam nooit horen noemen (CT1 36 - You are a man of intelligence and not so young anymore and yet you have never heard my name mentioned)

U, een ontwikkeld en bejaard iemand, hebt nooit van mij gehoord (CT2 397 - You, an educated and elderly person, have never heard of me)

Whereas the Russian author himself needed only 11 words for this clause, the first translator required almost twice this amount of words -20 - to express roughly the same. From this point of view the retranslator managed to restore Chekhov's style to a certain extent and reduced the Dutch sentence to only 11, which is quite an achievement, taking into account that Dutch, unlike Russian, uses articles, and therefore usually needs more words than Russian to express the same narrative.

The restoration of stylistic elements from the ST in retranslation is one of the features that is traditionally linked with the so-called Retranslation Hypothesis (see Berman for the initial idea, and Chesterman for the further development of the concept), which states that first translations are meant to introduce a certain literary text into another literary system, but are always incomplete, which is why retranslations are necessary to restore the typical features of the ST. Our corpus, indeed, also shows a number of cases where stylistic features from the ST, that had been left out from the first translation, have been restored in the retranslations: 
(4) ... мучше мечтать. Намечтать можно ... (DS 289 - better dreaming. It is possible to dream ...)

De droom $<\ldots>$ fantaseren ... (DT1 $703-$ The dream $<\ldots>$ to fantasize)
... je kunt beter dromen. In je dromen ... (DT2 704 - you can better dream. In your dreams
...)

In this example, we notice how the repetition of the verb "to dream" in Russian (мeumamb) is avoided for stylistic reasons in the first translation (Dutch literary language in general avoids the use of too many repetitions), but restored in the retranslation, thus bringing the translation stylistically closer to the ST.

Another characteristic of the retranslations in the corpus is that the retranslators show more respect for the idiosyncrasies of the ST, again translating away from the previous version:

(5) впереди их старшая, Катишь (TS 93 - in front their eldest, Katish)

vóór hen de oudste, Katja (TT1 99 - in front of them their eldest, Katya)

voor hen de oudste, Katisj (TT2 104 - in front of them their eldest, Katish)

In this example, the first translator clearly tried to avoid confusion in the Dutch reader, who was perhaps not supposed to grasp that Katisj is one of the many forms that exist for the name Ekaterina (Екатерина) in Russian. By choosing Katja instead, the 1966 translator used a more familiar form of the name that was far better known to the audience. However, the 2006 retranslator takes for granted that the contemporary reader will see the link between the names and restores an element from the Russian version that was lost during the first translation process, even if the form Katisj is not more familiar now than it was in the 1960s. Something similar happens in the same extract from $W$ ar and Peace, where the Coфu (Sofi in transliteration, TS 94) from the ST was first rendered by Sofja (TT1 100) in 1966, but restored to Sophie (TT2 10) in 2006.

\subsubsection{Similarities at Syntactic and Stylistic levels}

If so many elements from the first translations are replaced in retranslation, what is then retained, apart from a number of lexical choices that might have been made because there is no realistic alternative available that still sounds natural for a Dutch-speaking reader? And how can we find out which of the features from the first translation are retained without interviewing the retranslators about their translation strategy?

It is, indeed, very difficult to prove traces of the previous translation that go beyond the obvious level of lexical choices made by the first translator. As we have seen before (4.2.1), retranslation is often a question of refreshing, as well as the removal of outdated language.

Even if retranslators have the disadvantage that their effort will always be compared with a previous translation, which might urge them to aim for an exaggerated reaction against their predecessor, they also have the advantage that they have the power to judge the decisions by their predecessors and to preserve any part of the previous translation that is considered successful. In 
the following example, for instance, the translators had a range of different possibilities at their disposal to render the Russian but they finally settled for an almost identical solution:

(6) разлегся на бархатном диване, сладко потянулся и задремал (CS 270 - lay down on a velvet sofa, stretched sweetly and dozed off)

vlijde zich op de fluwelen bank neer, rekte zich behagelijk uit en sluimerde in (CT1 35 - lay down on the velvet sofa, stretched comfortably, and fell asleep)

vlijde zich neer op zijn fluwelen bank, rekte zich behaaglijk uit en dommelde in (CT2 396 - lay down on his velvet sofa, stretched comfortably, and fell asleep)

Words and expressions such as zich neervlijen and beha(a)g(e)lijk are of rather elevated register and the choice for this particular group of words in one sentence most probably proves influence from the previous translation. These are the cases where one could expect that the retranslator approved of the choices made by the first translator and decided not to alter the first translation, which still does not sound outdated and correctly reproduces the content of the ST.

\section{Conclusions}

In Translation Studies the difference between retranslation and revision has been touched upon on a regular basis, but research has not been able, so far, to define a clear border line between the two processes, which have a lot in common, but should still be considered as separate activities. At least subjectively, a retranslator is "more highly valued" than a reviser (Koskinen 316), and the concept retranslation surely has more economic potential for a publishing house than revision, so the question is relevant.

The analysis of a small sample of literary translations from Russian into Dutch has shown that retranslations, despite their very individual nature, still have some hallmarks in common. For instance, they show a surprisingly constant percentage of lexical overlap with their respective predecessors. Indeed, the retranslations that have been examined in this paper all retain approximately $50-60 \%$ of the lexical items in general, and a similar amount of verbs and nouns in particular, from the previous translations. The question is whether the retranslators would have made the same lexical choices if they had been the first translators, and hence had not had a predecessor at their disposal, which could be checked for inspiration in places that displayed specific translational difficulties.

The example of two parallel translations, used as a means of comparison in this paper, suggests that two translators, independently of each other, come up with a similar amount of the same translation solutions. This would assume that roughly half of the lexical items in a literary text have a natural and obvious translation equivalent that does not constitute real difficulty for the translator, and therefore can safely be retained by a retranslator without risking criticism of plagiarism. The other half of a text is where the real job for a literary translator begins. And that job often includes an update of those elements in translation (not only lexical, but also syntactic and stylistic) that are no longer accepted within the literary norms of the receiving culture. The number of clear findings by the previous translator that are kept in the retranslation is, after all, very limited. 
Retranslation, at least in the case of the three explored retranslations from the Russian Library series, does not seem to lead to an excessive borrowing of lexical translation solutions by the previous translator, nor does the act of retranslating seem to lead to the extreme denial of the interpretation of the previous translator. The lexical overlap between different translations of one and the same text is rather constant, and does not significantly vary from the overlap that exists between two parallel translations, which confirms the presupposition that a translator has only a limited number of ways to translate a ST and should not try to diverge further from an older translation than necessary. In many cases the lexical diversity of the translations is only slightly altered by the retranslator, but what s/he actually does, is rebuilding a new kind of narrative, making use of the same building blocks as the previous translation, but reordering them in such a way that they create a new and innovative look on the ST.

At the same time, a number of questions still remain. What, for instance, if the same exercise applied to a much larger corpus of translations and retranslations? The choice of a small sample for this study undoubtedly influenced the final results, but this finding does not alter the fact that the concurrence of quantitative results is surprisingly high. The analysis in this paper seems to suggest that an overlap of $50-60 \%$ is natural. Does this mean that a significantly higher percentage of overlap (of for instance $80 \%$ ) implies that we are dealing with a revision? And does an overlap of more than $60 \%$ between 2 translations imply that the retranslator committed plagiarism of some kind? How far can, or should, a retranslation of prose fiction diverge from an older version without harming the originality level? Attempts have been made to answer these questions, at least within the Turkish context, where abundant evidence of plagiarism and "fake translations" was uncovered in recent publishing practices (see Şahin, Duman and Gürses for a discussion of the issue).

Another question concerns the genre of the translated text and the languages involved. This case study included only Dutch translations of Russian prose fiction, but my hypothesis would be that retranslations between other languages may react differently to examples of ageing, and that retranslation of poetry and drama will differ more significantly from their predecessors. In the case of poetry, that is presumably so because formal characteristics take precedence over the content of the work, which gives the retranslator the opportunity to pick words from a much broader range of semantic fields and with different musicality. In the case of drama, the need to keep the play performable urges the retranslator to remove more outdated linguistic features from the translation than is the case with prose fiction. 


\section{REFERENCES}

\section{Primary Sources}

Dostojevski, Fjodor. De broers Karamazov. Translated by Arthur Langeveld, van Oorschot, 2005. . De gebroeders Karamazow. Translated by Jan van der Eng, van Oorschot, 1958.

Odojevski, Vladimir. Het jaar 4338 en andere verbalen. Translated by Aai Prins, Hoogland en Van Klaveren, 2011.

Odojevski, Vladimir. Het Jaar 4338. Translated by Willem Weststeijn, Pegasus, 2011.

Tolstoj, Leo. Oorlog en vrede. Translated by H.R. de Vries, van Oorschot, 1966.

- Oorlog en vrede. Translated by Yolanda Bloemen \& Marja Wiebes, van Oorschot, 2006.

Tsjechov, Anton. "De passagier eerste klas." Verzamelde werken. Deel II. Verbalen 1885-1886. Translated by Tom Eekman, van Oorschot, 2005.

. "De passagier eerste klas." Verzamelde werken. Deel II. Verhalen 1886-1887. Translated by Charles B. Timmer, van Oorschot, 1954.Аостоевский, Ф.М. Братья Карамазовы. Роман в четырех частях с эпилогом. Том 2. Современник, 1981.

ОАоевский, ВАадимир. "4338-й год. Петербургские письма." Русская фантастическая проза XIX - начала ХХ века, сост. Ю. Медведев, Правда, 1986, с. 121-154.

Толстой, Аев. Война и мир. Том 1-2. Азбука, 2014.

Чехов, Антон. Полное собрание сочинений и писем в тридиати томах. Сочинения в восемнадиати mомах. Том 5. Наука, 1976.

\section{Secondary Sources}

Alevato do Amaral, Vitor. "Broadening the notion of retranslation." Cadernos de Tradução, vol. 39, no. 1, 2019, pp. 239-259. http://dx.doi.org/10.5007/2175-7968.2019v39n1p239.

Berman, Antoine. "La retraduction comme espace de la traduction." Palimpsestes, vol. 4, 1990, pp. $1-7$.

Chesterman, Andrew. "A Causal Model for Translation Studies." Intercultural Faultlines: Research Models in Translation Studies I: Textual and Cognitive Aspects, edited by Maeve Olohan, St. Jerome, 2000, pp. 15-28.

Even-Zohar, Itamar. "Polysystem Studies." Poetics Today, vol. 11, no. 1, 1990.

Hartman, Menno. "Re: Vraag in verband met de 'Russische Bibliotheek'." Received by Piet Van Poucke, 20 September 2019.

Koskinen, Kaisa. "Revising and Retranslating." The Routledge Handbook of Literary Translation, by Washbourne, Kelly and Ben Van Wyke (eds.), Routledge, 2018, pp. 315-324.

Mair, Christian. Twentieth-century English: History, Variation and Standardization. Cambridge University Press, 2006.

Paloposki, Outi, and Kaisa Koskinen. "Reprocessing Texts. The Fine Line between Retranslating and Revising." Across Languages and Cultures, vol. 11, no. 1, 2010, pp. 29-49. https://akademiai.com/doi/abs/10.1556/Acr.11.2010.1.2.

Racz, Gregory. "No Anxiety of Influence: Ethics in Poetry Retranslation after Analogical Form." Translation Review, vol. 85, no. 1, 2013, pp. 42-58. 
Şahin, Mehmet, Duman, Derya, and Sabri Gürses. "Big business of plagiarism under the guise of (re)translation: The case of Turkey." Babel, vol. 61, no. 2, 2015, pp. 193-218. https://doi.org/10.1075/babel.61.2.03sah.

Steiner, George. After Babel : Aspects of Language and Translation. Oxford university press, 1975.

"Style." Merriam-Webster Dictionary, 2019, Merriam-Webster. www.merriamwebster.com/dictionary/style. Accessed 27 September 2019.

"Syntax." Merriam-Webster Dictionary, 2019, Merriam-Webster. www.merriamwebster.com/dictionary/syntax. Accessed 27 September 2019.

Van Coillie, Jan. "Nibble, Nibble like a Mouse. Who is Nibbling at the Source Text's House. Retranslating Fairy Tales: Untangling the Web of Causation." La retraduction en littérature de jeunesse / Retranslating Children's Literature, Douglas, Virginie and Florence Cabaret (eds.), Peter Lang, 2014, pp. 39-52.

van der Horst, Joop, and Kees van der Horst. Geschiedenis van het Nederlands in de twintigste eeun. Standaard uitgeverij, 1999.

Van Poucke, Piet. "Aging as a Motive for Literary Retranslation: A Survey of Case Studies on Retranslation." Translation and Interpreting Studies, vol. 12, no. 1, 2017, pp. 91-115. https://doi.org/10.1075/tis.12.1.05van.

Venuti, Lawrence. "Retranslations: The Creation of Value." Bucknell Review, vol. 47, no. 1, 2004, pp. 25-38. 